dr inż. Zbigniew Durzyński, prof. nadzw.

mgr inż. Jarosław Królikowski

dr in: Rafal Cichy

Instytut Pojazdów Szynowych „,TABOR”

\title{
Porównanie wymagań dla pojazdów interoperacyjnych w świetle przepisów unijnych i krajowych
}

\begin{abstract}
Artykut przedstawia kilka wybranych różnic w wymaganiach dla pojazdów interoperacyjnych między przepisami krajowymi, a Unii Europejskiej. W pierwszej części omówione zostały przepisy prawa wraz z przywołanymi normatywami oraz proces ich legislacji. Następnie zestawiono oraz omówiono różnice między przepisami krajowymi, a Unii Europejskiej. Wnioski przeznaczone sq dla podmiotów działajacych $w$ szeroko rozumianej gałęzi transportu szynowego $i$ wskazuja kierunek rozwoju produktów, aby jak najbardziej ułatwić proces ich dopuszczenia do stosowania w Polsce i/lub Europie. Dodatkowo, niniejszy artykut można wykorzystać jako kompendium wiedzy na temat aktualnie stosowanych przepisów dotyczqcych transportu kolejowego.
\end{abstract}

\section{WPROWADZENIE}

Interoperacyjność oznacza możliwość współdziałania różnych odrębnych organizacji na rzecz osiagnięcia uzgodnionych i korzystnych dla wszystkich stron celów, przy jednoczesnym dzieleniu się informacjami i wiedzą pomiędzy tymi organizacjami poprzez wspierane przez nie procesy biznesowe, za pomocą wymiany danych za pośrednictwem odpowiednich systemów.

Celem interoperacyjności systemu kolei wspólnoty europejskiej jest ułatwienie migracji pojazdów kolejowych mimo różnic $\mathrm{w}$ wyposażeniu infrastruktury kolejowej jej krajów członkowskich.

Warunkiem koniecznych do wydania przez dowolny organ bezpieczeństwa krajowego (w Polsce Urząd Transportu Kolejowego) zezwolenia na dopuszczenie pojazdu kolejowego do eksploatacji, niezbędnego do dostępu do europejskiej infrastruktury kolejowej, jest pozytywna ocena pojazdu dokonana wg ściśle ustalonych procedur. Procedury te określone są w szeregu dokumentach, poczynając od [3], [11] oraz [1] i [5], na krajowych rozporządzeniach [4] oraz [6]:[10] kończąc.

Wymagania dla podsystemu „TABOR”, podlegające ocenie zgodnie z [1] (zał. H), odnoszą się do kilku faz życia pojazdu:

- przegląd projektu

- badanie typu

- badanie okresowe.

Wymagania te są podstawą opracowania projektu konstrukcyjno-technologicznego nowego lub modernizowanego pojazdu, jego wytworzenia, procedur i programów badań przez akredytowane laboratoria oraz dokumentacji systemu utrzymania, będącej podstawą prac przeglądowo-naprawczych, w ramach których wykonywane są niezbędne badania okresowe.

System kolei podzielono na następujące podsystemy:

a) strukturalne:

- infrastruktura

- energia

- sterowanie - urządzenia przytorowe

- sterowanie - urządzenia pokładowe

- tabor,

b) eksploatacyjne:

- ruch kolejowy

- utrzymanie

- aplikacje telematyczne dla przewozów pasażerskich i dla przewozów towarowych.

Podsystem „TABOR” ma odniesienia do następujących podsystemów i interfejsów:

- energia (Decyzja 2011/274/UE)

- infrastruktura (Decyzja 2011/275/UE)

- ruch kolejowy (Decyzja 2009/107/WE)

- sterowanie (Decyzja 2012/88/UE)

-aplikacje telematyczne (Rozporządzenie 454/2011)

- tabor kolejowy - hałas (Decyzja 2011/229/UE)

- osoby o ograniczonej możliwości poruszania się (Decyzja 2008/164/WE)

- bezpieczeństwo w tunelach kolejowych (Decyzja 2008/163/WE).

Oceny pojazdu zgodnego z wszystkimi TSI dokonują notyfikowane jednostki certyfikujące na podstawie badań wykonanych przez akredytowane laboratoria badawcze. W przypadku pojazdu niezgodnego z TSI czynności te przeprowadzają podmioty uprawnione. 
2. PRZEPISY DEFINIUJĄCE WYMAGANIA DLA SYSTEMU KOLEI WE

Na czele przepisów prawnych dla systemu kolei WE, w tym dla pojazdów kolejowych, znajduje się Dyrektywa [3] z późniejszymi zmianami. Daje ona delegację Komisji dla wydania decyzji lub rozporządzeń wprowadzających w życie Techniczne Specyfikacje Interoperacyjności dla wszystkich podsystemów systemu kolei na terenie WE.

Drugim nurtem są przepisy krajowe, $\mathrm{z}$ dokumentem nadrzędnym jakim jest Ustawa [11], która z kolei upoważniła właściwego ministra do wydania szeregu rozporządzeń związanych z interoperacyjnością.

Dla podsystemów niezgodnych z TSI dla kolei interoperacyjnej obwiązuje rozporządzenie [9], które przywołuje listę Prezesa UTK.

Dla kolei nieinteroperacyjnej minister wydał rozporządzenia dotyczące jej podsystemów: metra, bocznic i podsystemów na wąski tor [4], [6], [7] i [8].

Zgodnie z dyrektywą [3] weryfikacja spełnienia wymagań dla pojazdów zgodnych z TSI może dotyczyć jedynie:

a) technicznej zgodności odpowiednich podsystemów pojazdu i ich bezpiecznego zamontowania

b) technicznej zgodności pojazdu z odpowiednią siecią

c) krajowych przepisów mających zastosowanie do punktów otwartych

d) krajowych przepisów mających zastosowanie do szczególnych przypadków należycie określonych w odpowiednich TSI,

natomiast weryfikacja spełnienia wymagań dla pojazdów niezgodnych z TSI może dotyczyć jedynie:

e) aspektów technicznych ujętych w TSI, o ile istnieja, wg procedury weryfikacji WE

f) do pozostałych aspektów technicznych zastosowanie mają przepisy krajowe.
Sposób wprowadzenia tych przepisów w życie przedstawiono poniżej. Poniżej przedstawiono wszystkie dokumenty normatywne zamieszczone w TSI „Tabor lokomotywy i tabor pasażerski".

Pozycje zaznaczone wytłuszczoną kursywą dotyczą także specyfikacji dla wagonów towarowych [5], w której podane są ponadto następujące normy.

1. EN 15611:2008+ A1:2010

2. EN 15624:2008+ A1:2010

3. EN 15625:2008+ A1:2010

4. EN 15687:2010

5. EN 15807:2011

6. EN 15827:2011

7. EN 15839:2012

8. EN 15877-1:2012

9. EN 286-3:1994

10. EN 286-4:1994

11. EN 50343:2003

12. EN 50355:2003

13. ISO 5658-2:2006/A1:2011

14. Pr EN 16235

15. TS 45545-7:2009

16. UIC $430-1: 2006$

17. UIC 430-3:1995

18. UIC 535-2:2006

19. UIC 540:2006

20. UIC 541-1:2010

21. UIC 542:2010

22. UIC 575:1995

23. Dokument techniczny Agencji ERA/TD/2012-04/ INT wersja $1.0 \mathrm{z}$ dnia 4.6.2012

24. EN 12082:2007+ A1:2010

25. EN 13262: $2004+\mathrm{A} 1: 2008+\mathrm{A} 2: 2011$

26. EN 13501-1:2007+ A1:2009

27. EN 14601:2005+ A1:2010

28. EN 15085-1-5:2007

29. EN 15355:2008 + A1:2010

30. EN 15528:2008EN 15551:2009+ A1:2010

\author{
1. EN $12663-1: 2010$ \\ 2. EN $13103: 2009$ \\ 3. EN $13104: 2009$ \\ 4. EN $13260: 2009$ \\ 5. EN 13306 \\ 6. EN $1363-1: 1999$ \\ 7. EN $13674-1: 2003$ \\ 8. EN $13674-1: 2003 / \mathrm{A} 1: 2007$ \\ 9. EN $13715: 2006$ \\ 10. EN 13749 : 2005 \\ 11. EN $13848-1$ \\ 12. EN $13848-1: 2003 / \mathrm{A} 1: 2008$ \\ 13. EN $13979-1: 2003$ \\ 14. EN $13979-1: 2003 / A 1: 2009$ \\ 15. EN $14067-4: 2005 / \mathrm{A} 1: 2009$ \\ 16. EN $14198: 2004$
}

17. EN $14363: 2005$

18. EN $14531-1: 2005$

19. EN $14531-6: 2009$

20. EN $15152: 2007$

21. EN $15153-1: 2007$

22. EN $15153-2: 2007$,

23. EN $15227: 2008$

24. EN 15273 - 2: 2009

25. EN 15302:2008

26. EN 15437 - 1:2009

27. EN $15551: 2009$

28. EN $15566: 2009$

29. EN $15595: 2009$

30. EN $15686: 2010$

31. EN $45545-2$

32. EN $50119: 2009$
33. EN $50125-1: 1999$

34. EN 50153 : 2002

35. EN $50206-1: 2010$

36. EN $50317: 2002$

37. EN $50318: 2002$

38. EN $50367: 2006$

39. EN $50388: 2005$

40. EN $50405: 2006$

41. EN $60721-3-5$ :

1997

42. CSM

43. UIC 541 - 1

44. UIC $541-06$

45. UIC 627 - 2

46. UIC 648

47. UIC 651 
Należy zwrócić uwagę na istotne różnice między wymaganiami zawartymi w TSI [1] i w rozporządzeniu krajowym [9], zwłaszcza dotyczącymi składników interoperacyjności. Przykładowo dla koła i zestawu kołowego wymagania te są określone w poz. 27 i 28 listy Prezesa UTK. Normy dotyczące tych elementów wymienione w TSI Lok\&pas zaznaczono na czerwono.

Na liście Prezesa Urzędu Transportu Kolejowego, stanowiącej załącznik do [9] dla podsystemu „TABOR” ujętych jest 200 zakresów, od „Konstrukcji pojazdu” do "Ograniczenia w zakresie konstrukcji, eksploatacji oraz utrzymania dotyczące ładunków niebezpiecznych", a w każdym zakresie od jednej do kilkunastu regulacji krajowych, w zdecydowanej większości norm PN-EN oraz PN oraz kart UIC.

Ile $\mathrm{z}$ tych ponad kilkuset uwzględnionych $\mathrm{w}$ [9] regulacji odpowiada ww. wymaganiom wg. powyższych pkt. a) $\div$ f), tzn. nie są ujęte w TSI, a dotyczą wymaganych regulacjami europejskimi wymagań wynikających ze specyficznych dla polskiej infrastruktury interfejsów $\mathrm{z}$ podsystemami oraz punktów otwartych $\mathrm{i}$ przypadków szczególnych?

\section{WYMAGANIA DLA WYBRANYCH ELE- MENTÓW KONSTRUKCYJNYCH}

Ze względu na obszerność zagadnienia i ograniczone ramy referatu wyniki analizy wymagań zostały ograniczone do kilku wybranych zakresów.

Parametry zewnętrznych świateł czołowych

Zagadnieniem, któremu poświęcono wiele uwagi podczas przygotowania wymagań w Polsce a jednocześnie pokazującym różnice pomiędzy prawem krajowym i europejskim są światła czołowe. Wymagania zostały opisane w TSI „Lokomotywy i wagony pasażerskie” w punkcie 4.2.7.1.1 „Światła czołowe”. Polskim odpowiednikiem proponowanych w TSI wymagań jest punkt 96 dla podsystemu „TABOR” (numeracja wg. pkt. 4a) Listy Prezesa Urzędu Transportu Kolejowego, załącznika do [9]). Tablica 2 pokazuje fragment tabeli z listy wymagań krajowych zawierających punkt 96.

Tablica 2 - Wymagania dotyczące lamp czolowych

\begin{tabular}{|c|c|c|}
\hline Lp. & $\begin{array}{l}\text { Zakres wyma- } \\
\text { gań }\end{array}$ & Wymagania krajowe \\
\hline 96 & $\begin{array}{l}\text { Wizualne i } \\
\text { dźwiękowe } \\
\text { funkcje identy- } \\
\text { fikacji i ostrze- } \\
\text { gania dla pojaz- } \\
\text { du. Światła } \\
\text { zewnętrzne } \\
\text { czołowe }\end{array}$ & $\begin{array}{l}\text { PN-EN 15153-1 (światła dolne), } \\
\text { UIC } 534 \text { (światła górne) } \\
\S 105 \text { rozporządzenia w sprawie } \\
\text { ogólnych warunków prowadzenia } \\
\text { ruchu } \\
\text { PN-K-88200,UIC } 651 \text { (wyd. 2) }\end{array}$ \\
\hline
\end{tabular}

Odpowiadające zapisy z punktu 4.2.7.1.1 TSI „Lokomotywy i wagony pasażerskie", wybrane z uwagi na przedstawienie niezgodności, przedstawiono poniżej:
„W przypadku „pełnego światła” minimalna światłość mierzona wzdłuż optycznej osi lampy musi odpowiadać wartościom wyszczególnionym w normie EN 15153-1:2007, pkt 5.3.5, tabela 2, wiersz pierwszy."

Cytowane wymagania przedstawiają te fragmenty, które mają największy wpływ na powstanie różnic $\mathrm{w}$ wybranych punktach.

W tablicy 3 zebrano wszystkie parametry dotyczące świateł wynikające z zapisów zarówno TSI jak i Listy Prezesa Urzędu Transportu Kolejowego.

Tablica 3 - Wymagania dotyczące światłości lamp czołowych

\begin{tabular}{|c|c|c|c|c|}
\hline \multirow[b]{2}{*}{ Lp. } & \multirow{2}{*}{$\begin{array}{l}\text { Parametr } \\
\text { mierzony }\end{array}$} & \multicolumn{3}{|c|}{ Parametr wymagany wg: } \\
\hline & & $\begin{array}{c}\text { PN-K- } \\
88200: 200 \\
2[\mathrm{~cd}]\end{array}$ & $\begin{array}{c}\text { UIC } 534 \\
\text { pkt } 2.6 \text { i } 2.7 \\
\text { [cd] }\end{array}$ & $\begin{array}{c}\text { PN-EN } \\
15153-1 \\
{[\mathrm{~cd}]}\end{array}$ \\
\hline 1 & $\begin{array}{l}\text { Światłość } \\
\text { projektora } \\
\text { górnego } \\
\text { długie / } \\
\text { krótkie }\end{array}$ & \multirow{3}{*}{$\begin{array}{l}\text { Brak } \\
\text { wyma-gań } \\
\text { dla świateł } \\
\text { czoło- } \\
\text { wych }\end{array}$} & $\begin{array}{l}12000 \div \\
16000 *)\end{array}$ & $\begin{array}{l}300 \div 700 \\
/ \\
? 100\end{array}$ \\
\hline 2 & $\begin{array}{l}\text { Światłość } \\
\text { projektora } \\
\text { lewego } \\
\text { długie / } \\
\text { krótkie }\end{array}$ & & \multirow{2}{*}{$>12000 *)$} & \multirow{2}{*}{$\begin{array}{l}40000 \div \\
70000 / \\
12000 \div \\
16000\end{array}$} \\
\hline 3 & $\begin{array}{l}\text { Światłość } \\
\text { projektora } \\
\text { prawego } \\
\text { długie / } \\
\text { krótkie }\end{array}$ & & & \\
\hline
\end{tabular}

Dla parametrów oznaczonych *) należy spełnić dodatkowy warunek stosunku natężenia światła górnego do dolnego $\leq 1: 3$.

Analizując wartości powyższej tabeli należy zauważyć, że wymagania dla świateł czołowych są spójne tylko dla projektorów dolnych. W obu przypadkach wymagania są równe dla reflektora dolnego, gdzie ustalono wartość natężenia światła $40000 \div 70000$ [cd]. W przypadku projektora górnego wartości są różne. Norma PN-EN 15153-1, przywołana w TSI jako właściwa do oceny świateł, podaje wartości, które sprowadzają projektor górny do roli światła sygnałowego. W wymaganiach krajowych projektor górny powinien przyjmować wartości $12000 \div 16000$ [cd], czyli traktowany jest jako reflektor.

Zauważyć należy, że punkt 4.2.7.1.1 TSI „Lokomotywy i wagony pasażerskie" nie jest punktem otwartym, ani nie stanowi przypadku szczególnego charakterystycznego dla wymagań Polskiej infrastruktury. Oznacza to, że pojazd zgodny z TSI, posiadający odpowiedni certyfikat weryfikacji WE wystawiony przez notyfikowaną jednostkę certyfikującą nie będzie się mógł poruszać po infrastrukturze w Polsce, co zaprzecza idei interoperacyjności. 
W punkcie 96 wymagań krajowych znajduje się dodatkowo zapis: „§105 rozporządzenia w sprawie ogólnych warunków prowadzenia ruchu", czyli Rozporządzenia Ministra Infrastruktury z dnia 18 lipca 2005 r. w sprawie ogólnych warunków prowadzenia ruchu kolejowego i sygnalizacji (Dz. U. nr 172 poz. 1444). W $\$ 105$ ww. rozporządzenia przedstawione zostały rodzaje sygnałów, które powinny być wyświetlane na czole pojazdu. Wymaganie obejmuje wszystkie możliwe kombinacje sygnałów, w tym sygnały alarmowe. Wymaganie jest również charakterystyczne dla pojazdów poruszających się po linii kolejowej w Polsce i nie ma swojego odpowiednika w TSI.

Kolejnym punktem zawierającym różnice jest na Liście Prezesa Urzędu Transportu Kolejowego punkt 100 „Urządzenia ostrzegawcze. Sygnały urządzenia ostrzegawczego" i odpowiadający mu w TSI „Lokomotywy i wagony pasażerskie” punkt 4.2.7.2.2 „Poziomy dźwięku urządzenia ostrzegawczego". Zgodnie z zapisami TSI poziom dźwięku z korekcją częstotliwości według krzywej $\mathrm{C}$, wytwarzanego oddzielnie przez każde źródło (albo w grupie przy jednoczesnej emisji w formie akordu) powinien wynosić od $115 \mathrm{~dB}$ do 123 dB. Lista Prezesa UTK podaje jako wyznacznik oprócz normy PN-EN 15153-2 kartę UIC 644 „Ostrzegawcze sygnały dźwiękowe na pojazdach trakcyjnych w komunikacji międzynarodowej". Poziom dźwięku wg kart UIC 644 wynosi 120 [dB] do $125[\mathrm{~dB}]$. Zgodnie $\mathrm{z}$ tymi przepisami pojazd zgodny $\mathrm{z}$ polskimi wymaganiami w górnej granicy nie będzie spełniał wymagań TSI, a $\mathrm{w}$ dolnej granicy pojazd zgodny z TSI będzie niezgodny z polskimi wymaganiami.

\section{Wybrane parametry hamulca}

Kolejnym bardzo ważnym aspektem, któremu poświęcono uwagę jest skuteczność hamowania hamulcem postojowym. Szczegółowe wymagania zostały omówione w rozdziale 4.2.4.5.5. TSI „Lokomotywy i wagony pasażerskie" [1]. Odpowiednikiem tego punktu $\mathrm{w}$ przepisach krajowych jest punkt 45 dla podsystemu „TABOR” na Liście Prezesa Urzędu Transportu Kolejowego.

Poniższa tabela nr 4 przedstawia wymagania krajowe.

Tablica 4 - Wymagania dotyczące skuteczności hamowania hamulca postojowego

\begin{tabular}{|c|c|c|}
\hline LP & $\begin{array}{c}\text { Zakres } \\
\text { wymagań }\end{array}$ & Wymagania krajowe \\
\hline 45 & $\begin{array}{c}\text { Skuteczność } \\
\text { hamowania. } \\
\text { Hamulec } \\
\text { postojowy }\end{array}$ & UIC 543; UIC 544-1 \\
\hline
\end{tabular}

Przywołane w powyższej tablicy wymagania krajowe to:

- UIC 543 - Hamulec - Przepisy dotyczące wyposażenia wagonów

- UIC 544-1 - Hamulec - Hamowność.
Zgodnie z wymaganiami powyższych kart UIC:

- wagony osobowe muszą być wyposażone w śrubowy hamulec ręczny obsługiwany od wnętrza wagonu kołem pokrętnym.

- układ mechaniczny hamulca ręcznego śrubowego powinien być tak wykonany, by wagon próżny był pewnie utrzymywany na spadku 35 $\%$ przy sile $0,5 \mathrm{kN}$ na kole pokrętnym (nie obowiązuje dla wagonów osobowych $\mathrm{z}$ hamulcem tarczowym, które zostały zbudowane przed 31.12.1983).

- masa hamująca wyznaczona jest wg ustaleń karty UIC 544-1 i powinna być opisana z zewnątrz wagonu według karty UIC 545.

Odpowiadające im zapisy $\mathrm{z}$ punktu 4.2.4.5.5. TSI „Lokomotywy i wagony pasażerskie” są następujące. Skuteczność:

- jednostka (pociagg lub pojazd) przy stanie obciążenia „masa projektowa bez obciążenia użytkowego", bez dostępnego zasilania oraz trwale nieruchoma na torze o nachyleniu $35 \%$, musi pozostawać unieruchomiona.

- unieruchomienie uzyskuje się za pomocą funkcji hamowania postojowego oraz środków dodatkowych (np. płóz hamulcowych) w przypadku gdy sam hamulec postojowy nie jest w stanie osiagnąć tej skuteczności; wymagane środki dodatkowe muszą być dostępne na pokładzie pociagu.

Obliczenia:

- w przypadku jednostki (pociagu lub pojazdu) skuteczność hamowania postojowego oblicza się W sposób określony normą EN145316:2009. Wynik (nachylenie, przy którym pojazd kolejowy pozostaje unieruchomiony za pomocą samego hamulca postojowego) musi być zapisany $\mathrm{w}$ rejestrze taboru określonym w pkt. 4.8 niniejszej TSI.

Po przeanalizowaniu wymagań można stwierdzić, że krajowe wymagania są o wiele bardziej szczegółowe aniżeli te przywołane w TSI „Lokomotywy i wagony pasażerskie". Podają siłę, jaką należy przyłożyć do koła pokrętnego, aby skutecznie pojazd unieruchomić. Wskazują także wyraźnie, że hamulec postojowy powinien być możliwy do uruchomienia z wnętrza wagonu - informacji takiej w TSI nie ma. Dodatkowo, każdy z dokumentów przywołuje inne metody obliczeń skuteczności hamulca postojowego.

Innym omawianym aspektem jest zabezpieczenie przed poślizgiem kół w trakcie hamowania. Szczegółowe wymagania zostały omówione w rozdziale 4.2.4.6.2. TSI „Lokomotywy i wagony pasażerskie” [1]. Odpowiednikiem tego punktu w krajowych przepisach prawa jest punkt $47 \mathrm{z}$ Listy Prezesa Urzędu transportu Kolejowego dla podsystemu „TABOR”.

Poniższa tablica nr 4 przedstawia wymagania krajowe: 
Tablica 5 - Zarządzanie przyczepnością w trakcie hamowania. Zabezpieczenie przed poślizgiem kół

\begin{tabular}{|c|c|c|}
\hline LP & Zakres wymagań & Wymagania krajowe \\
\hline \multirow{4}{*}{47} & Zarządzanie przy- & \\
& $\begin{array}{c}\text { czepnością w trakcie } \\
\text { hamowania. Zabez- } \\
\text { pieczenie przed } \\
\text { poślizgiem kół. }\end{array}$ & PN-EN 15595; UIC \\
& & \\
\hline
\end{tabular}

Przywołane w powyższej tablicy wymagania krajowe to:

- PN-EN 15595 - Hamowanie - Urządzenia przeciwpoślizgowe

- UIC 541-05 - Hamulce - Przepisy dotyczące budowy różnych części hamulca - Urządzenie przeciwpoślizgowe.

Zarówno TSI, jak i przepisy krajowe wg Listy Prezesa UTK dopuszczają stosowanie normy PN-EN 15595. Jednak należy zwrócić uwagę, że Lista Prezesa UTK dopuszcza zastosowanie wymagań wg karty UIC 54105 . Opis funkcji systemu w obydwu normatywach jest zbliżony.

Przepisy TSI wymagają obecności systemu w pojeździe przystosowanym do maksymalnej prędkości eksploatacyjnej wyższej niż $150 \mathrm{~km} / \mathrm{h}$. Ani karta UIC 541-05 ani norma PN-EN 15595 nie definiują wymagań odnośnie obecności systemu $\mathrm{w}$ zależności od prędkości maksymalnej pojazdu, mowa jest jedynie o tym, że „pojazdy poruszające się z prędkością powyżej $200 \mathrm{~km} / \mathrm{h}$ powinny być wyposażone oprócz urządzenia WSP również w urządzenie monitorujące (tzw. urządzenie nadzorujące toczenie), które wykrywa zablokowane osie i sygnalizuje ten fakt w kabinie maszynisty".

Dodatkowe wymagania dotyczące obecności i użytkowania systemu przeciwpoślizgowego $\mathrm{w}$ pojeździe wg TSI są następujące:

- pojazdy kolejowe wyposażone w klocki hamulcowe na powierzchni tocznej kół o skuteczności hamowania, dla której przyjmuje się obliczeniową przyczepność koło/szyna wyższą niż 0,12 , muszą być wyposażone w system zabezpieczenia przed poślizgiem kół.

- pojazdy kolejowe niewyposażone w klocki hamulcowe na powierzchni tocznej kół o skuteczności hamowania, dla której przyjmuje się obliczeniową przyczepność koło/szyna wyższą niż 0,11 , muszą być wyposażone w system zabezpieczenia przed poślizgiem kół.

- wymaganie dotyczące powyższego systemu zabezpieczenia przed poślizgiem kół ma zastosowanie do dwóch trybów hamowania: hamowania nagłego i hamowania służbowego.

Stosuje się je również w przypadku układu hamulca dynamicznego, który stanowi część hamulca służbowego i może stanowić część systemu hamowania nagłego.
Pomimo widocznych różnic w wymaganiach dla wyżej wymienionych punktów (najczęściej polskie wymagania odsyłają do kart UIC, natomiast wymagania wg TSI podaja normy PN-EN) to są one do siebie zbliżone, różnice te jednak nie wynikają ze specyfiki polskiej infrastruktury kolejowej.

\section{Parametry pantografu}

Jednym z przykładów zgodności i braku zgodności wymagań krajowych z ideą Dyrektywy są poniżej skomentowane punkty (numeracja wg. pkt. 4a) załącznika do [9].

Wymagania dotyczące „Obciążalności prądowej pantografu", wg poz. 122, określone są w normie PN-EN 50206- 1, natomiast rozmieszczenie pantografów w normie PN-EN 50367. Według [1] należy posługiwać się w tych przypadkach tymi samymi normami europejskimi. W tym przypadku lista norm odpowiada zaleceniom dyrektywy.

Wymagania wg. poz. 106 odnoszące się do „Parametrów funkcjonalnych i technicznych dotyczących interfejsu między pojazdem a podsystemem „energia” określone są w szeregu normach europejskich oraz w kilku normach krajowych:
a. PN EN 50163
b. PN EN 50206-1
c. PN EN 50367
d. PN EN 50388
e. PN EN 50405
f. PN-K 23011: Tabor kolejowy. Elektryczna insta- lacja zasilania urządzeń wagonowych. 01.1998
g. PN-K 91001: Elektryczne pojazdy trakcyjne. Odbieraki prądu. 12.1997

Według [1] należy posługiwać się w tych przypadkach normami wymienionymi w pkt. a. $\div$ e.

Kluczowe dla oceny zasadności wymagań jest zatem skomentowanie norm wg poz. f. i g.

Norma w pozycji f. podaje np.:

a) poziomy dopuszczalnych zakłóceń nieaktualne w świetle wprowadzonego przez UTK obowiązku stosowania wymagań z pracy Instytutu Kolejnictwa 4430/10,

b) normy dotyczące wymagań na przewody elektryczne pochodzące nawet z 1968 r., przykładowo:

\begin{tabular}{l} 
„Przewody powinny być zgodne z wymaga- \\
niami: PN-E-90042:1976 (PN-76/E-90042), \\
PN-E-90104:1991 (PN-91/E-90104), PN-E- \\
90116:1988 (PN-88/E-90116), $\quad$ PN-E- \\
90120:1968 (PN-68/E-90120) i \\
\hline 90121:1968 (PN-68/E-90121)".
\end{tabular}


Norma z poz. g. dotyczy bezpośrednio odbieraków, zatem powinna była zostać zamieszczona co najwyżej w poz. 116, jeśli wnosi wymagania inne niż wynikające $\mathrm{z}$ przywołanych $\mathrm{w}$ tym punkcie norm. W odniesieniu do tego punktu można stwierdzić dalszą niekonsekwencję. Przywołana norma PN-EN 50119 odnosi się do sieci trakcyjnej i tylko przywołuje normy właściwe dla odbieraków prądowych, zatem w tym miejscu jest zbędna.

\section{ROZBIEŻNOŚCI MIĘDZY WYMAGANIA- MI TSI A REGULACJAMI KRAJOWYMI}

Poza rozbieżnościami przedstawionymi w wyżej, należy zauważyć, że w pkt 5.4 zalecenia 2011 /217/UE stwierdza się, co następuje:

„Z tego względu, aby zapewnić przejrzystość, państwa członkowskie powinny jasno określić w swoich przepisach krajowych, które z nich odnosza się do wszystkich podsystemów $w$ eksploatacji, a które obowiqzuja jedynie $w$ odniesieniu do nowych i modernizowanych lub odnowionych podsystemów, które maja uzyskać zezwolenie na dopuszczenie do eksploatacji”.

Ten punkt został pominięty w regulacjach krajowych.

\section{PODSUMOWANIE}

Oprócz oczywistych trudności dla projektantów pojazdów, szczególnie dla ruchu międzynarodowego, wynikających $\mathrm{z}$ zaprezentowanych różnic, istotną kwestia jest postawienie pytania ile takich bardziej lub mniej istotnych różnic występuje pomiędzy wymaganiami krajowymi i TSI.

Niezgodności między wymaganiami krajowymi i z TSI z zaprezentowanych różnic stwarzają oczywiste trudności dla projektantów pojazdów, szczególnie przeznaczonych do ruchu międzynarodowego.

Niezbędne jest podjęcie prac, które doprowadzą do ujednolicenia przepisów i wyeliminują zagadnienia budzące wiele kontrowersji i zbędnych emocji. Instytucją, która powinna podjąc takie działania jest narodowy organ bezpieczeństwa (NSA), którym w Polsce jest Urząd Transportu Kolejowego.

Obecny stan tworzy paradoksalną sytuację, że pojazd zgodny z TSI dopuszczony $w$ innym kraju UE nie będzie zgodny $\mathrm{z}$ niektórymi polskimi przepisami, które nie dotyczą ani punktów otwartych i przypadków szczególnych, ani specyfiki polskiej infrastruktury.

Przytoczone przypadki wskazują na to, że pojazd zgodny z TSI, posiadający odpowiedni certyfi-kat weryfikacji WE wystawiony przez notyfikowana jednostkę certyfikującą i zezwolenie euro-pejskiego NSA, nawet zgodny ze specyfiką polskiej infrastruktury, nie będzie się mógł poruszać po infrastrukturze w Polsce, co zaprzecza idei interoperacyjności.

Należy znowelizować polskie przepisy techniczne, po pierwsze opierając je na logicznych i konsekwentnych zasadach, zgodnie z duchem europejskich dyrektyw i zaleceń, oraz po drugie odchodząc od wygodnego założenia „na wszelki przypadek wpisać wszystko co wiemy”, na rzecz sparafrazowanej maksymy „lepiej wiedzieć co się pisze, niż pisać wszystko co się wie". Wtedy przepisy krajowe nie będą składały się z wielu setek norm krajowych i europejskich, kart UIC i innych regulacji, zawierających nie dających się pogodzić wymagań, lecz podobnie jak Techniczne Specyfikacje Interoperacyjności będą zawierały tylko kilkadziesiąt istotnych.

\section{Bibliografia}

[1] Decyzja Komisji nr 2011/291/UE z dnia 26 kwietnia 2011 r. w sprawie technicznej specyfikacji interoperacyjności odnoszqcej się do podsystemu „,Tabor - lokomotywy i tabor pasazerski" $w$ transeuropejskim systemie kolei konwencjonalnych

[2] Durzyński Z.: Procedury dopuszczenia do eksploatacji pojazdów kolejowych oraz procedury oceny zgodności składników interoperacyjności świetle znowelizowanej ustawy o transporcie kolejowym. Seminarium „Najnowsze regulacje prawne $w$ zakresie interoperacyjności”. Warszawa. 9-10.10.2012 r.

[3] Dyrektywa Parlamentu Europejskiego $i$ Rady 2008/57/WE z dnia 17 czerwca 2008 r. w sprawie interoperacyjności systemu kolei we Wspólnocie (z poźn. zmianami)

[4] Rozporzqdzenie Ministra Infrastruktury i Rozwoju z dnia 13 maja 2014 r. w sprawie dopuszczenia do eksploatacji określonych rodzajów budowli, urzq̨dzeń $i$ pojazdów kolejowych (Dz. U. 2014 poz. 720

[5] Rozporzadzenie Komisji (UE) nr 321/2013 z dnia 13 marca $2013 r$. dotyczace technicznej specyfikacji interoperacyjności odnoszacej się do podsystemu ,,Tabor wagony towarowe" systemu kolei w Unii Europejskiej i uchylajqce decyzje 2006/861/WE

[6] Rozporzadzenie Ministra Transportu, Budownictwa i Gospodarki Morskiej z dnia 7 sierpnia 2012 r. w sprawie wykazu typów ....... pojazdów kolejowych, na które sq wydawane świadectwa dopuszczenia do eksploatacji typu (Dz. U. 2012 r. poz. 911)

[7] Rozporzqdzenie Ministra Transportu, Budownictwa $i$ Gospodarki Morskiej z dnia 7 sierpnia 2012 r. w sprawie zakresu badań koniecznych do uzyskania świadectw ... (Dz. U. 2012 r. poz. 918)

[8] Rozporzadzenie Ministra Transportu, Budownictwa $i$ Gospodarki Morskiej z dnia 7 listopada 2012 r. w sprawie świadectw dopuszczenia do eksploatacji typu (Dz. U. 2012 r. poz. 919)

[9] Rozporzadzenie Ministra Transportu, Budownictwa I Gospodarki Morskiej z dnia 27 grudnia 2012 r. w sprawie wykazu właściwych krajowych specyfikacji technicznych i dokumentów normalizacyjnych, których zastosowanie umożliwia spetnienie zasadniczych wymagań dotyczacych interoperacyjności systemu kolei (Dz. U. 2013 r. poz. 43)

[10]Rozporzadzenie Ministra Transportu, Budownictwa $i$ Gospodarki Morskiej z dnia 6 listopada 2013 r. w sprawie interoperacyjności systemu kolei (Dz. U. 2013 r. poz. 1297)

[11]Ustawa z dnia 7 sierpnia 2012 r. o transporcie kolejowym (Dz. U. 2003 r. nr 86 poz. 789 z późn. zmianami) 